\title{
Concluding Remarks
}

\author{
Gerry Simpson
}

On the 7th of June, 2012, Hannah, Rosa and I attended the launch of the then-latest edition of the fiction magazine, Etchings, held in Readings bookstore in St Kilda, just opposite the site where the famous Jewish café Scheherazade had stood. Deborah's grandfather, Benjamin Cass, had been a regular at Scheherazade for 20 years (more or less until his death at 104, almost twice the age Deborah was when she died).

Four writers were there to read from recently published work. Two women recited passages from their own worthy memoirs and were followed by a booming man recounting some hugely unerotic 'erotic adventures'. He clearly imagined himself to be the star speaker that evening. Right up until the point when Deborah began reading. She read - with such charm, poise and authority - a passage from her short story, 'Her Beauty as a Sword' (about her grandmother, Eva Shulman). ${ }^{1}$ The room was captivated.

It was the last time Deborah spoke in public, and the story was the last work she published.

But Deborah and her work have had such powerful afterlives. I still see references to her Nordic Journal essay, 'Navigating the Newstream' (a brilliantly clever title, if I may say so), her superb tour d'horizon of the Newstream movement in international law. ${ }^{2}$ Meanwhile the constitutionalisation of trade law book is a standard reference (discussed recently at an American Society event) and her other work pops up very

Deborah Cass, 'Her Beauty as a Sword' (2011) 10 Etchings 5-12.

Deborah Cass, 'Navigating the Newstream: Recent Critical Scholarship in International Law' (1996) 65 Nordic Journal of International Law 341, doi.org/10.1163/15718109620294924. 
frequently. Cait Storr was kind enough to reference Deborah recently in Tbilisi when she spoke about Nauru. My students continue to quote her. They probably have no idea that I was married to her for 20 years.

Deborah left so much behind: friends (she had the best friends, as Catriona Drew once told me), ideas, ways of seeing and being, cousins, nieces, nephews, a brother, a sister, a mother, a father, a husband and two daughters. And now, this book can be added to Deborah's afterlife.

So, I could not be more grateful to Kim and Hilary (two of Deborah's dear friends and hugely admired colleagues), for organising the conference from which this book arises, and to Deborah's friends and colleagues (and brother, Dan). They write so beautifully about her public life and her private world or both; Catherine Hawkins describes talking feminist politics over the back fence in Narrabundah with Deborah, and Dan's piece is a fluent and moving tribute to the various private and public Deborahs we knew and didn't know.

Deborah told me, shortly after I met her, that she had published her undergraduate essay in public international law. We were both international law tyros at this point so I felt vaguely disturbed by this news. At that point, I had published nothing (unless we count a poem about John Lennon in the 1980 edition of Thor, the Thurso High School Magazine). Worse still, she was merely a tutor whereas I had ascended to the heady heights of 'lecturer in law (continuing)' at Melbourne University. After professing a total lack of interest in this news, I searched out her essay immediately. It had an irredeemably boring title (something like 'The Quiet Revolution: International Law and Fishing on the High Seas') but, disappointingly, it was, like Margaret Young's return to that subject in these pages, rather good. ${ }^{3}$

A few months later, still in the midst of a faltering campaign to win her heart, I took her to Jimmy Watson's Wine Bar in Carlton where she dropped another bombshell: her essay on self-determination (celebrated here in Tony Anghie's affectionate tribute to her work on Nauru) had been accepted by The Syracuse Journal of International Law. ${ }^{4}$ I muttered something about not having a clue where Syracuse was but I knew then

3 Deborah Cass, 'A Quiet Revolution: The Exclusive Economic Zone and Foreign Fishing Access in the Pacific' (1987) 16 Melbourne University Law Review 83.

4 Deborah Z Cass, 'Re-Thinking Self-Determination: A Critical Analysis of Current International Law Theories' (1992) 18 Syracuse Journal of International Law and Commerce 31. 
that the die was cast. Deborah was on the move, and quickly. I hastily knocked off an essay on some recent international law case and then, in imitation of Deborah, I rehashed my Master's thesis on self-determination and persuaded the Stanford Journal of International Law to publish it.

It was a breathless and prolix retread of Deborah's elegant dissection of the same subject.

By the time it was published, Deborah had published our first daughter, Hannah, and the battle was over.

Deborah always seemed to be one step ahead, not just of me, but of nearly everyone. Feminist constitutional law (with Kim), the revival of trusteeship as an international legal doctrine, the turn to histories of the discipline, the emergence of trade law, the constitutionalisation of trade law: Deborah was there first or a close second.

But the book on trade law was, really, what Kerry Rittich calls a 'groundclearing exercise. ${ }^{5}$ Further books would follow: on trade and democracy, on campaign finance, a critical study of Nauru and trusteeship. There would be a magnum opus on international law and redistribution, then a (first) novel called $A$ History of Boyfriends. Each of them 'fresh and forthright and full of luminous, funny phrases', in the words Susan Marks used to describe Deborah's writing.

But none of this happened. Life got in the way. Then death.

Or maybe it did happen (some of it at least) but was carried out by others in their own distinctive and distinguished way. When I read these essays I feel Deborah's spirit and intelligence in the pages. When Tony Anghie speaks of Nauru and Australia's various imperialisms, Deborah's archival research and thinking is so very evident (not least in Tony's generous acknowledgments).

Margaret Young's conviction, expressed in her wide-ranging retrospective, that fisheries law is a way into understanding not just important aspects of the law of the sea but also what she calls the 'allocation of sovereignties' at the heart of international law, is a conviction that Margaret is right to say would be shared by Deborah.

5 See in this volume, Kerry Rittich, 'Deborah Cass, The Constitutionalization of the World Trade Organization: A Reading in Time'. 
Deborah did not collaborate often in her academic career but the fruits of a rare and important collective effort are discussed by Kim Rubenstein in her essay on representations of women in Australian constitutional life and politics. Here, Kim returns to an essay she and Deborah published in the Adelaide Law Review in $1995 .{ }^{6}$ I think what Deborah appreciated most about this prescient essay was its potential to inspire change beyond the academy. It is to Kim's enormous credit that the article has had such a powerful afterlife in Australian constitutional thought and that Kim and others are prepared to use the essay and recent English jurisprudence (Cope7) as a departure point for thinking of job-sharing (a subject to which Deborah's illness made her highly attuned) as a constitutional issue. One of Deborah's great friends from her Harvard days and beyond, Kerry Rittich, has offered here a wonderfully creative reading of Deborah's prize-winning book on The Constitutionalization of the World Trade Organization. As she puts it:

Deborah ... was one of the first people to seriously consider the idea that the idea of the WTO - how it was conceived as an institution, how it imagined the community of states and other actors engaged in trade relations, and the ethos and values that organised these relations and informed the operation of the regime as a whole - was an independently significant field of inquiry. ${ }^{8}$

How we wish that such work could have been continued by Deborah; how grateful we are that this work is being pursued with such rigour and imagination by those close to her.

Deborah's friends have done her an enormous service in these pages. When this book is launched; when we pick it up and read these sparkling essays, we will experience both Deborah's powerful presence, and her absence.

6 Deborah Cass and Kim Rubenstein, 'Representations of Women: Towards a Feminist Analysis of the Australian Constitutional System' (1995) 17 Adelaide Law Review 3.

$7 \quad R$ (Cope) v Returning Officer for the Basingstoke Parliamentary Constituency [2015] EWHC 3958 (Admin).

8 See in this volume, Kerry Rittich, 'Deborah Cass, The Constitutionalization of the World Trade Organization: A Reading in Time'. 
This text is taken from Traversing the Divide: Honouring Deborah Cass's Contributions to Public and International Law, edited by Kim Rubenstein, published 2021 by ANU Press, The Australian National University,

Canberra, Australia.

doi.org/10.22459/TD.2021.09 